\title{
UPAYA MENURUNKAN ANGKA KEMISKINAN MELALUI PROGRAM BIMBINGAN BAGI MASYARAKAT PRASEJAHTERA
}

\author{
Nana Darna*, Wiwin Setianingsih \\ Fakultas Ekonomi Universitas Galuh \\ *Email: fakultasekonomi@unigal.ac.id
}

\begin{abstract}
ABSTRAK
Program pengabdian pada masyarakat ini memiliki tujuan: (1) Meningkatkan motivasi bekerja dan meminimalisasi rasa malas masyarakat prasejahtera yang ada di Desa Pamalayan, Cijeungjing, Kabupaten Ciamis; (2) meningkatkan pengalaman dan keterampilan bekerja masyarakat prasejahtera yang ada di Desa Pamalayan Cijeungjing, Kabupaten Ciamis; dan (3) meningkatkan ketekunan bekerja masyarakat prasejahtera yang ada di Desa Pamalayan, Cijeungjing, Kabupaten Ciamis. Metode yang digunakan dalam kegiatan pengabdian ini adalah metode pengembangan kaji tindak. Metode Pengembangan Kaji Tindak merupakan upaya metode pengembangan program yang dilakukan secara komprehensif yang dimulai dari kegiatan pengkajian secara mendalam terhadap faktor potensi, pendukung, dan penghambat program yang diikuti dengan tindakan nyata pelaksanaan program. Tujuan akhir metode ini adalah terlaksananya program secara efektif dan efisien. Secara teknik program ini akan dilaksanakan dalam 6 langkah pelaksanaan program, yaitu: (1) pembentukan komitmen, (2) bimbingan kesadaran dan motivasi, (3) bimbingan keterampilan, (4) bimbingan ketekunan bekerja, (5) bimbingan penguatan karakter kewirausahaan, dan (6) evaluasi program bersama. Melalui keenam tahapan kegiatan ini diharapkan tujuan dan target yang telah ditetapkan dapat tercapai.
\end{abstract}

Kata kunci: Angka kemiskinan, bimbingan, masyarakat prasejahtera

\section{PENDAHULUAN}

Salah satu persoalan mendasar yang dihadapi seluruh negara adalah perihal kemiskinan. Kemiskinan menjadi salah satu tolak ukur mendasar bagi kemajuan sebuah negara. Sejalan dengan hal tersebut, setiap negara senantiasa melaksanakan berbagai program untuk memberantas kemiskinan. Program ini bahkan di beberapa negara menjadi program utama yang tentu saja dalam pelaksanaannya dilaksanakan secara terintegrasi dengan programprogram lain yang berkaitan.

Sejalan dengan uraian di atas, kemiskinan merupakan masalah kompleks yang dipengaruhi oleh berbagai faktor yang saling berkaitan, antara lain: tingkat pendapatan, kesehatan, pendidikan, akses terhadap barang dan jasa, lokasi, geografis, gender, dan kondisi lingkungan. Mengacu pada strategi nasional penanggulangan kemiskinan, definisi kemiskinan adalah kondisi di mana seseorang atau sekelompok orang, laki-laki dan perempuan, tidak terpenuhi hak-hak dasarnya untuk mempertahankan dan mengembangkan kehidupan yang bermartabat. Hak-hak dasar yang diakui secara umum meliputi terpenuhinya kebutuhan pangan, kesehatan, pendidikan, pekerjaan, perumahan, air bersih, pertanahan, sumber daya alam, dan lingkungan hidup, rasa aman dari perlakukan atau ancaman tindak kekerasan dan hak untuk berpartisipasi dalam kehidupan sosial-politik, baik bagi perempuan maupun lakilaki (Badan Pusat Statistik Provinsi Jawa Barat, 2018a). 
Definisi kemiskinan lain tertuang dalam Peraturan Daerah Kabupaten Ciamis Nomor 11 Tahun 2016 yang menyatakan bahwa pada dasarnya kemiskinan adalah suatu ketidakmampuan seseorang, atau keluarga, atau masyarakat dalam memenuhi kebutuhan hakhak dasar dan akses terhadap sumber-sumber ekonomi produktif sebagai aset penghidupan berkelanjutan untuk mempertahankan dan mengembangkan kehidupan yang bermartabat sesuai dengan potensi di sekitarnya. Sejalan dengan definisi ini, suatu penduduk dikatakan merupakan penduduk miskin apabila memiliki rata-rata pengeluaran per kapita per bulan di bawah garis kemiskinan. Garis kemiskinan merupakan suatu representasi dari jumlah rupiah minimum yang dibutuhkan untuk memenuhi kebutuhan pokok minimum makanan dan kebutuhan pokok bukan makanan (Badan Pusat Statistik Provinsi Jawa Barat, 2018).

Persoalan kemiskinan juga merupakan masalah utama yang dihadapi bangsa Indonesia. Dalam lingkup provinsi, kemiskinan juga dihadapi oleh provisi Jawa Barat. Berdasarkan Badan Pusat Statistik Provinsi Jawa Barat (2018b) perkembangan tingkat kemiskinan pada kurun waktu bulan Maret 2017 - Maret 2018 di Jawa Barat menunjukkan tren menurun. Pada keadaan Maret 2017, persentase penduduk miskin di Jawa Barat mencapai 8,71 persen $(4,17$ juta jiwa). Dan pada keadaan September 2017 mengalami penurunan sebesar 0,88 persen menjadi 7,83 persen (3,77 juta jiwa). Penurunan tingkat kemiskinan yang terjadi selama kurun waktu September 2017 - Maret 2018 ini diiringi pula dengan kondisi perekonomian penduduk Jawa Barat mengalami perubahan ke arah positif.

Tren positif menurunnya tingkat kemiskinan di Jawa Barat tidak sejalan dengan kondisi di tingkat kabupaten khususnya Kabupaten Ciamis. Berdasarkan pernyataan Kepala BPS Kabupaten Ciamis, Erna Tresna Prihatin, S.Si, (https://www.harapanrakyat.com/2016) di Kabupaten Ciamis jumlah penduduk miskin dari tahun 2013 tercatat 100,804 jiwa atau 8,58 persen. Pada tahun 2014 penduduk miskin mengalami penurunan mencapai 99,810 jiwa atau mencapai 8,44 persen. Namun angka tersebut mengalami kenaikan pada tahun 2015. Pada tahun 2015 jumlah penduduk miskin di Kabupaten Ciamis mencapai 104,870 jiwa atau sekitar 8,98 persen. Data terbaru dari Badan Pusat Statistik Provinsi Jawa Barat (2016), jumlah keluarga miskin Kabupaten Ciamis menurun menjadi hanya sebesar 79.639.

Masih banyaknya jumlah keluarga miskin di Kabupaten Ciamis dapat dipahami karena masih terdapatnya daerah kantong-kantong kemiskinan. Daerah kantong kemiskinan di Kabupaten Ciamis rupanya tidak hanya berada di kecamatan-kecamatan yang jauh dari ibu kota kabupaten. Di Kecamatan Cijeungjing saja sampai dengan tahun 2017 masih ada keluarga yang prasejahtera atau keluarga miskin sebanyak 1.816 keluarga (Badan Pusat Statistik Kabupaten Ciamis, 2018). 
Desa Pamalayan sebagai salah satu desa yang terletak di Kecamatan Cijeungjing Kabupaten Ciamis merupakan salah satu desa dengan jumlah penduduk miskin dengan jumlah yang cukup banyak yakni sejumlah 351 keluarga dengan perincian sebanyak 132 keluarga miskin karena alasan ekonomi dan 219 keluarga miskin non alasan ekonomi (Badan Pusat Statistik Kabupaten Ciamis, 2018). Banyaknya jumlah keluarga miskin di Desa Pamalayan rupanya sejalan dengan rendahnya jumlah penduduk yang memiliki pekerjaan tetap yang tercatat paling rendah dibanding dengan 10 desa lain yang ada di Kecamatan Cijeungjing. Penduduk Desa Pamalayan ditinjau dari status perkerjaannya tercatat 1.058 orang sebagai petani, 203 orang sebagai peternak, 14 karyawan industri/perusahaan, 14 orang PNS, 10 orang buruh angkutan, dan 144 orang sebagai pedagang. Jika ditinjau dari komposisi pekerjaannya sangat wajar jika jumlah penduduk miskin atau prasejahtera jumlahnya masih cukup banyak di Desa Pamalayan (Badan Pusat Statistik Kabupaten Ciamis, 2018).

Sejalan dengan kondisi di atas, upaya menurunkan angka penduduk miskin di Desa Pamalayan harus dilakukan dengan terlebih dahulu mengklasifikasikan penduduk miskin pada dua kelompok besar yakni penduduk miskin karena kemiskinan kultural dan penduduk miskin struktural. Berdasarkan data, hampir seluruh penduduk miskin di Desa Pamalayan sebenarnya terkategori sebagai penduduk miskin golongan kedua. Penduduk miskin golongan kedua tersebut muncul sebagai akibat ketidakberdayaan mereka terhadap sistem atau tatanan sosial yang tidak adil maupun akibat dari rasa malas atau rendahnya motivasi dalam memanfaatkan potensi ekonomi yang ada pada dirinya dan lingkungan alam sekitarnya. Sejalan dengan hal tersebut, upaya utama yang harus dilakukan untuk menurunkan tingkat kemiskinan pada kelompok kedua ini adalah dengan memberikan penyadaran dan motivasi bekerja. Oleh sebab itu, program pengabdian yang akan dilakukan adalah memberikan penyuluhan dan bimbingan kepada masyarakat prasejahtera.

Program pengabdian pada masyarakat ini memiliki tujuan-tujuan sebagai berikut: (1) Meningkatkan motivasi bekerja dan meminimalisasi rasa malas masyarakat prasejahtera yang ada di Dusun Pende Desa Pamalayan, Cijeungjing, Kabupaten Ciamis, (2) Meningkatkan pengalaman dan keterampilan bekerja masyarakat prasejahtera yang ada di Dusun Pende Desa Pamalayan Cijeungjing, Kabupaten Ciamis, dan (3) Meningkatkan ketekunan bekerja masyarakat prasejahtera yang ada di Dusun Pende Desa Pamalayan, Cijeungjing, Kabupaten Ciamis. 


\section{MATERI DAN METODE PELAKSANAAN}

Wilayah pelaksanaan kegiatan ini adalah Desa Pamalayan Kecamatan Cijeungjing Kabupaten Ciamis. Khalayak sasaran utama kegiatan pengabdian ini adalah warga masyarakat prasejahtera yang ada di Desa Pamalayan Kecamatan Cijeungjing Kabupaten Ciamis. Karena banyaknya jumlah keluarga prasejahtera yang ada di Desa Pamalayan, dalam praktiknya kegiatan ini dilaksanakan secara terbatas di Kampung Pende dengan melibatkan kurang lebih 20 keluarga prasejahtera yang ada. Khalayak sasaran utama adalah ibu-ibu rumah tangga yang memang tidak memiliki pekerjaan tetap.

Pelaksanaan kegiatan pengabdian pada masyarakat ini dilaksanakan melalui beberapa tahapan sebagai berikut:

Tahap 1: Pembentukan Komitmen Bersama, dilakukan melalui kegiatan diskusi dengan warga masyarakat dan ketua RT setempat.

Tahap 2: Bimbingan Kesadaran dan Motivasi. Kegiatan dilakukan dengan model bimbingan psikologi sehingga kegiatan tidak bersifat menggurui peserta kegiatan.

Tahap 3: Bimbingan Keterampilan. Pada tahapan ini memberikan bimbingan keterampilan pada warga masyarakat dalam rangka mengembangkan potensi yang dimilikinya dan dukungan sumber daya yang ada.

Tahap 4: Bimbingan Ketekunan Bekerja. Pada tahap ini tim memberikan bimbingan warga masyarakat dalam membangun peluang pasar dan memperluas lingkup pemasaran produk secara digital.

Tahap 5: Penyuluhan Penguatan Karakter Kewirausahaan. Pada tahap ini akan dilakukan kegiatan pembinaan khusus bagi masyarakat tentang perlu tetap menjaga semangat dan terus meningkatkan kerja keras.

Tahap 6: Evaluasi Pengembangan Bersama. Kegiatan ini dilakukan untuk melihat ada tidaknya perkembangan yang lebih baik.

Metode yang digunakan dalam kegiatan pengabdian ini adalah metode pengembangan kaji tindak. Metode pengembangan kaji tindak merupakan upaya metode pengembangan program yang dilakukan secara komprehensif yang dimulai dari kegiatan pengkajian secara mendalam terhadap faktor potensi, pendukung, dan penghambat program yang diikuti dengan tindakan nyata pelaksanaan program. Tujuan akhir metode ini adalah terlaksananya program secara efektif dan efisien.

Secara teknis pelaksanaan program ini akan dilakukan secara kolaboratif dan kooperatif. Hal ini berarti antara tim pelaksana dan khalayak sasaran akan secara bersama-sama berupaya mencapai tujuan bersama dengan berlandaskan asas saling asah, saling asuh, dan saling 
percaya. Melalui asas ini diharapkan akan timbul kedekatan secara psikologi antara tim dengan khalayak sasaran. Sebagai diketahui bahwa kuberhasil program bimbingan dan penyuluhan itu sendiri akan sangat bergantung pada kedekatan psikosis antara pembimbing dan yang dibimbing.

\section{HASIL DAN PEMBAHASAN}

\section{Tahap Sebelum Pengabdian}

Sebagai langkah awal pada kegiatan lapangan ini adalah ijin pada aparat setempat untuk melakukan survey ke lokasi di Dusun Pende Rt 08 Rw 03 Desa Pamalayan Kecamatan Cijeungjing, kegiatan ini bertujuan untuk mengidentifikasi masalah-masalah yang ada di lapangan dengan cara mengamati bagaimana tingkat kesejahteraan untuk masyarakat pra sejahtera di lingkungan tersebut dengan memprioritaskan bagi keluarga yang masih produktif dan lebih difokuskan pada ibu-ibu muda, hal ini sangat penting karena jika Keluarga pra sejahtera produktif tapi tidak diberdayakan akan menimbulkan masalah negatif contoh bertambahnya angka pengangguran. Dari hasil survey kurang lebih ada 20 keluarga produktif dijadikan target yang diundang mengikuti program bimbingan.

\section{Tahap Pelaksanaan Pengabdian}

Program bimbingan ini dilaksanakan pada hari Sabtu 5 Januari 2019. Tempat di Dusun Pende RT 08 RW 03 No 9 Desa Pamalayan Kecamatan Cijeungjing Kabupaten Ciamis. Pukul 09.00 s.d 12.00 WIB dan dihadiri oleh 9 peserta dari target 20 0rang peserta. Adapun tahapan dalam pelaksanaan sebagai berikut:

Tahap 1: Pembentukan Komitmen Bersama, dilakukan melalui kegiatan diskusi antara tim peneliti dengan warga masyarakat dan ketua RT atau RW setempat. Tujuan utama tahapan ini adalah terjalinnya komitmen bersama dalam melaksanakan program kegiatan pengabdian.

Tahap 2: Bimbingan Kesadaran dan Motivasi. Kegiatan ini dilakukan dalam bentuk sarasehan antara tim dan khalayak sasaran. Tujuan utama tahapan ini adalah terbentuknya motivasi dan kesadaran masyarakat tentang pentingnya memiliki motivasi bekerja. Kegiatan dilakukan dengan model bimbingan psikologi sehingga kegiatan tidak bersifat menggurui peserta kegiatan.

Tahap 3: Bimbingan Keterampilan. Pada tahapan ini tim memberikan bimbingan keterampilan pada warga masyarakat dalam rangka mengembangkan potensi yang dimilikinya dan dukungan sumber daya yang ada. Tujuan utama kegiatan ini adalah 
meningkatnya keterampilan masyarakat menghasilkan berbagai produk kreatif sesuai dengan kemampuan yang dimilikinya.

Tahap 4: Bimbingan Ketekunan Bekerja. Pada tahap ini tim memberikan bimbingan warga masyarakat dalam membangun peluang pasar dan memperluas lingkup pemasaran produk secara digital. Dengan demikian, tujuan utama kegiatan ini adalah meningkatkan ketekunan dan kesabaran dalam memasarkan produk yang mereka hasilkan.

Tahap 5: Penyuluhan Penguatan Karakter Kewirausahaan. Pada tahap ini akan dilakukan kegiatan pembinaan khusus bagi masyarakat tentang perlu tetap menjaga semangat dan terus meningkatkan kerja keras. Tujuan kegiatan ini adalah terbentuknya jiwajiwa tangguh yang tidak gampang menyerah dalam upaya meningkatkan taraf ekonomi masyarakat.

Tahap 6: Evaluasi Pengembangan Bersama. Kegiatan ini dilakukan untuk melihat ada tidaknya perkembangan yang lebih baik. Tujuannya untuk melakukan evaluasi secara terbuka pada seluruh pihak yang terlibat dalam kegiatan yang dilaksanakan.

\section{Tahap Setelah Pengabdian}

Langkah terakhir adalah melakukan monitoring dan evaluasi dengan cara melakukan silaturahmiatau kunjungan ke rumah masing-masing peserta, kegiatan monitoring dan evaluasi ini penting dilakukan untuk mengetahui bagaimana keberlanjutan dari hasil bimbingan. Selain hal tersebut dengan adanya kegiatan ini peserta merasa ada perhatian dan termotivasi. Dari hasil monitoring dan evaluasi peserta mulai menerapkan hasil dari program bimbingan.

Upaya pemberantasan kemiskinan tentu bukan semata-mata menjadi beban pemerintah, melainkan juga menjadi tanggung jawab bersama masyarakat. Sejalan dengan hal tersebut dalam menurunkan angka kemiskinan masyarakat perlu ada keterpaduan antara pemerintah, masyarakat, dan tentu juga kepedulian pihak swasta. Program pengabdian masyarakat ini melalui program bimbingan diharapkan mampu menurunkan angka kemiskinan dengan memperhatikan:

1. Rasa Malas pada Masyarakat untuk bekerja.

Guna menghilangkan rasa malas masyarakat prasejahtera akan dilakukan bimbingan dengan orientasi pada bimbingan kejiwaan dan pembangkitan motivasi bekerja. Pola bimbingan yang akan digunakan adalah pola bimbingan kelompok dengan menggunakan model simulasi permainan yang berorientasi pada pembangkitan kesadaran dan semangat 
bekerja.

2. Rendahnya akan Pengalaman dan Keterampilan Bekerja.

Guna memberikan pengalaman dan keterampilan bekerja bagi masyarakat prasejahtera desa Pamalayan akan dilakukan bimbingan dengan orientasi pada keterampilan kerja. Pola bimbingan yang akan digunakan adalah pola pembinaan keterampilan ekonomi kreatif sehingga timbul kesadaran akan potensi diri dan lingkungan dan pada akhirnya masyarakat diharapkan mampu menciptakan peluang ekonomi kreatif.

3. Rendahnya dalam Ketekunan Bekerja.

Guna membina ketekunan bekerja bagi masyarakat prasejahtera desa Pamalayan akan dilakukan bimbingan dengan orientasi pada pembentukan karakter kerja keras dan kerja cerdas. Pola bimbingan yang akan digunakan adalah pola studi kasus pemasaran produk melalui media digital sehingga timbul bahwa dengan kerja keras dan kerja keras akan mendatangkan penghasilan yang cukup dan meningkatkan daya tahan ekonomi keluarga.

\section{KESIMPULAN DAN SARAN}

\section{Kesimpulan}

1. Kegiatan pengabdian pada masyarakat melalui program bimbingan di Dusun Pende Desa Pamalayan Kecamatan Cijeunging Kabupaten Ciamis telah berjalan sesuai dengan apa yang telah direncanakan.

2. Bukti nyata keberhasilan program bimbingan ini adalah terbukanya pola pikir masyarakat dan mengaplikasikannya dalam kehidupan sehari-hari.

3. Keberhasilan program ini didukung oleh sejumlah faktor yang antara lain kerjasama yang baik dan aktif dari warga dan aparat setempat

4. Upaya mengurangi angka kemiskinan melalui program bimbingan pada keluarga prasejahtera yang produktif melalui pemberdayaan khusus pada ibu-ibu muda yang tidak mempunyai pekerjaan tetap dapat membawa perubahan ke arah positif dan menjadi termotivasi untuk berkembang untuk mendapatkan penghasilan. Setelah mengikuti program bimbingan dan mendapatkan pengetahuan mampu merubah pola pikir lebih maju lagi dalam hal mengatasi rasa malas untuk bekerja, meningkatnya keterampilan bekerja serta ketekunan masyarakat dalam bekerja.

5. Diharapkan pula mampu merangsang ibu-ibu muda sasaran untuk aktif mengambil keputusan dan berani mencari akar masalah yang dihadapi, serta mampu menggali potensinya, sehingga mampu mencari solusi dari permasalahanya. Pemberdayaan kaum ibu-ibu muda dengan pendekatan ekonomi merupakan realitas sosial yang sangat 
diharapkan masyarakat prasejahtera. Dengan adanya pemberian praktik keterampilan dengan menyesuaikan potensi lokal dapat mengembangkan usaha bersama ekonomi tentu ini juga dapat meningkatakan penghasilan bagi keluarga serta dapat membentuk kemandirian masyarakat.

\section{Saran}

1. Perlu adanya pengembangan program bimbingan secara berkelanjutan.

2. Perlu adanya dukungan pemerintah daerah dalam mengembangkan potensi sumber daya alam dan sumber daya manusia yang tersedia.

\section{DAFTAR PUSTAKA}

Badan Pusat Statistik Kabupaten Ciamis (2018) Kecamatan Cijeungjing dalam Angka 2017. Ciamis: BPS Kabupaten Ciamis.

Badan Pusat Statistik Provinsi Jawa Barat (2016) Provisi Jawa Barat dalam Angka 2016. Bandung: BPS Provinsi Jawa Barat.

Badan Pusat Statistik Provinsi Jawa Barat (2018a) Indikator Kesejahteraan Rakyat Provinsi Jawa Barat 2018. Bandung: BPS Provinsi Jawa Barat.

Badan Pusat Statistik Provinsi Jawa Barat (2018b) Perkembangan Tingkat Kemiskinan Provinsi Jawa Barat Maret 2018. Bandung: BPS Provinsi Jawa Barat.

Herlina, N. dan Komariah, M. (2017) "Peran Pemerintah dalam Pengentasan Kemiskinan di Kabupaten Ciamis". Galuh Justisi. 5(2) 260 - 277.

Peraturan Daerah Kabupaten Ciamis Nomor 11 Tahun 2016 tentang Penanggulangan Kemiskinan

Romli (2001LPenyuluhan Agama Menghadapi Tantangan Baru. Jakarta: Bina Rena Pariwara. Surya, M. (2015) Bimbingan dan Konseling. Bandung: Pustaka Cedikia.

Walgito, B. (2015) Bimbingan dan Konseling. Yogyakarta: ANDI Offset.

https://www.harapanrakyat.com/2016/11/penduduk-miskin-di-ciamis-dan-pangandaranmeningkat 